\title{
Analysis of the Effect of Exchange Value, Inflation, Product Sharing and Gross Domestic Products on Development Sharia Banking Assets in Indonesia
}

\author{
Muhammad Arif ${ }^{1}$, HB. Tarmizi SU' ${ }^{2}$, M. Syafi ${ }^{\prime 3}$ \\ ${ }^{1}$ Posgraduate Students Faculty of Economics and Business, Department of Economics, Universitas Sumatera \\ Utara, Indonesia \\ ${ }^{2,3}$ Postgraduate Lecturer Faculty of Economics and Business, Department of Economics, Universitas Sumatera \\ Utara, Indonesia
}

Corresponding Author: Muhammad Arif

\begin{abstract}
Islamic banks have had a significant development in assets, where during the last ten years the assets of Islamic banks reached 524 trillion rupiah in 2019. However, although the number of assets tends to increase, the percentage of Islamic bank assets grew slowly from 2016 to 2019. It was recorded that the growth of Islamic bank assets in 2016 grew by $22.10 \%$ (yoy) and finally in 2019 it grew by 9.93\% (yoy), in line with the slowdown in financing channeled by Islamic banks. Banks in their operational activities cannot be separated from the influence of economic conditions. In this study, using analysis from outside the company, namely by using analysis of the macroeconomic environment. Macroeconomic variables used are the exchange rate, inflation, and Gross Domestic Product (GDP), where these three factors are the impact of the global financial crisis in 2008, and greatly affect the condition of the Indonesian economy. As well as the internal factors of the bank itself, namely profit sharing. The purpose of this study is to determine how much influence the exchange rate, inflation, profit sharing, and GDP both partially and simultaneously affect the development of Islamic bank assets in Indonesia. This type of research is quantitative research with panel data. This study uses panel data regression analysis techniques, namely using data combining cross section and time series, where this research is carried out using the common effect, fixed effect and random effect model specification test using the Chow
\end{abstract}

test and the Hausman test. The population and sample of this study are the 10th quarterly financial reports of Islamic commercial banks in Indonesia using purposive sampling technique. The model chosen in this study is the Fixed Effect Model (FEM). The results showed that partially the exchange rate and inflation variables had a positive but insignificant effect on the development of Islamic bank assets, while the profit sharing variables and gross domestic product had a positive and significant effect on the development of Islamic bank assets. While simultaneously the exchange rate, GDP, inflation and profit sharing variables have a positive and significant effect on the development of Islamic bank assets.

Keywords: Exchange Rate, Inflation, Profit Sharing, GDP and Asset Development

\section{INTRODUCTION}

Economy as one of the forefront in the development of a Country requires the existence of a transformation to its business activities, where the purpose of the transformation efforts towards it is to increase performance and productivity in order to improve product competitiveness in global, so it can be exported to various Countries in order to increase revenue for the company and also increase the revenue of the State.

One of the companies that apply the transformation in the field of business is the banking industry. All the activities of the 
economic activity in the era of globalization is inseparable from the bank, where almost all economic activity is always utilizing the services of banking in the process of transaction, be it sale and purchase transactions, lending transactions credit, as well as transactions repayment of debt and receivables of the company.

In terms of how to determine a price the bank divided into two, namely conventional banks and islamic banks. A conventional Bank is a bank in the determination of the price of using interest as a remuneration, whether the remuneration received by the bank on the distribution of funds to the community, and the remuneration paid by the bank to the community for fund raising.

While Islamic banks are Banks that operate with do not rely on the interest. Islamic Bank or commonly called the Bank Without Interest, is a financial institution or banking operations and products are developed based on Al-Qur"an and Hadith of the Prophet. In other words, the islamic bank is a financial institution that payment as well as the circulation of money that its operation is adapted to the principles of Islamic sharia. As according to Law Number 21 Year 2008 about Sharia Banking Article 1, the definition of islamic banking is everything that concerns the islamic banks and sharia business units, covering institutional, business activities, as well as the way and process in carrying out its business activities".

The economic crisis in 1997 has made the Indonesian economy experienced a downturn. This is an impact to existing companies in the country especially in the banking sector. The banking sector is very dependent on the position of the exchange rate because their transactions using foreign currency. This further worsens the condition of the national economy, because the banking institution is one of the backbone of the economy of a Country and serves as an intermediary institution. The problems of banking are the occurrence of a negative spread, where the interest rate savings greater than the interest rate of the loan, so the banks hard earned profits. It is precisely inversely proportional to the Islamic Banks, because the income of Islamic Banks is not derived from the interest, therefore Islamic Banking is directly will not be dealing with negative spreads like the banks conventional. Because the main Income of the Islamic Banks focused on how much banks can collect profit from the investment in the real sector (Setiawan, 2009:37).

Indonesia has the opportunity as a country has a market share of sharia with the largest population of muslim population the largest in the world, as much as 254,9 million in the year 2015. Until December 2014, the islamic banking industry has a network of as many as 12 Sharia Banks (BUS), 24 Sharia Business Units (UUS), and $163 \mathrm{SRB}$, with a total network of offices reached 2.910 offices spread in almost all corners of the archipelago.

The rapid growth of islamic banking and resilience in the face of the economic crisis that hit Indonesia in 1998 the making of islamic banks earn the greater trust of society, so government and monetary authorities increasingly support the development of sharia banking in Indonesia. Travel time shows that islamic economics could be an option to overcome the problem which is still to be a global crisis.

The existence of islamic banking has existed since the era of the 90 's, i.e. since the enactment of the law on banking law no. 7 year 1992. Law number 7 year 1992 was a forerunner to the emergence of islamic banking, where the law is still set on the term for results. New in 1998 out of the banking law the latest law number 10 year 1998, which through the law is already set about the operational principles of the bank based on sharia, so that in the 2000s many emerging islamic banking and the demands of public banks either state-owned banks and private banks to create a sharia business unit, where sharia business unit this can help people who want to borrow money without any interest cost, so helping the community is spared from the bondage of a refund that 
large. With the development of islamic banking, thus was born the law on sharia banking, namely law no. 21 of 2008 , which explains about the rules of the legal foundation of islamic banking.

With the existence of law number 21 year 2008 has been rapid development towards islamic banking. One of the indicators to assess the success of islamic banking is to look at the value of the total assets of the islamic banking. The greater the amount of total assets of a bank, the better the position of the bank. Total assets can be influenced from both the macro economic and internal bank itself.

The growth of Assets of Sharia Banks in Indonesia shows the amount of assets of BUS and UUS in 2016 increased by $\mathrm{Rp} 60.242$ trillion to $\mathrm{Rp} 356.504$ billion compared to total assets of BUS and UUS in 2015 worth Rp.296.262 trillion. Is better than previous years which only increased by Rp 23.919 trillion in 2015 from 2014 which is an increase the least in the period 20122016. It can also be seen from Table 1.1 about the development of the total assets owned by islamic banks in Indonesia during the period from 2009 to 2019:

Table 1.1: The Development Of The Total Assets Of Islamic
Banks In The Period Of Years 2009 To 2019
\begin{tabular}{|l|c|l|}
\hline Year & $\begin{array}{l}\text { Total Assets of Islamic Banks in } \\
\text { Indonesia (Billion) }\end{array}$ & $\begin{array}{l}\text { Return On Asset } \\
\text { (ROA) (\%) }\end{array}$ \\
\hline 2009 & 66.090 .000 .000 & 1,10 \\
\hline 2010 & 97.619 .000 .000 & 1,60 \\
\hline 2011 & 146.467 .000 .000 & 1,80 \\
\hline 2012 & 196.018 .000 .000 & 1,20 \\
\hline 2013 & 242.276 .000 .000 & 1,35 \\
\hline 2014 & 272.545 .000 .000 & 1,97 \\
\hline 2015 & 296.262 .000 .000 & 1,81 \\
\hline 2016 & 356.504 .000 .000 & 2,47 \\
\hline 2017 & 424.181 .000 .000 & 1,77 \\
\hline 2018 & 477.827 .000 .000 & 2,24 \\
\hline 2019 & 624.684 .000 .000 & 2,04 \\
\hline \multicolumn{2}{|c|}{ Source : www.ojk.go.id } \\
\hline
\end{tabular}

Based on Table 1.1 above it can be seen that the amount of the total assets of islamic banks in Indonesia in the period 2009-2019 year tends to increase, while In the years 2009-2019 total return on assets, it tends to decrease, whereby despite an increase in the number of assets in islamic banks in Indonesia has not been able to provide increased significant against the rate of return on assets. It can be seen from the rate of return on assets (ROA) of islamic banks in Indonesia during the period of the year from 2009 to 2019 is likely to decrease.

The increase in the growth of islamic banks is very determined by how big the profit, where the profit earned islamic bank obtained from the increase in the number of assets through operational activities that have been implemented. The increase in total assets of islamic banks is sanat is influenced by several factors including external factors such as macro-economic factors, namely the factors of inflation and exchange rate, the Growth of Gross Domestic Product (GDP) as well as internal factors such as the rate factor for the results of the savings products of sharia banks.

According to Karim (2010: 28) inflation greatly affects the increase in assets of islamic banks, so that the increase in these assets will be able to increase the profitability of islamic banks itself, where profitability increased, then the rate of return on assets also increased. High inflation will make the effort of islamic banks in improving the income will be slightly disturbed, as a result of business of islamic banks in increasing the number of assets will also be disturbed. High inflation will make the occurrence of the decrease in the number of assets owned by islamic banks, as a result a strong push in raising the amount of assets to be slightly reduced, resulting in the least amount of profit obtained by islamic banks.

With at least an increase in assets and profits diperleh islamic bank, then the bank's ability to generate funds to disbursed in some of the products of islamic banks also decreased. This is an impact to the occurrence of a slight advantage in yield for the proceeds of a savings product with the customer, where the islamic banks have ability a little to increase profits to the rate for the results of the savings that owned by islamic banks to its customers.

On the contrary, if inflation is low, then the efforts of islamic banks in improving the income will be gained with 
better, as a result of business of islamic banks in increasing the number of assets will also be better. Low inflation will make the occurrence of an increase in assets maximum, as a result a strong push in raising the amount of assets to be also be a maximum, resulting in the increase in the amount of the maximum benefit obtained by islamic banks. With the increase in assets as well as the maximum profit, then the ability of banks in generating funds to disbursed in some of the products of islamic banks also has increased maximum. This is an impact to the occurrence of an increase in profits in return for the proceeds of a savings product with the customer, where the islamic bank is able to increase the distribution of profits to the rate for the results of the savings that owned by islamic banks to its customers.

According to Huda, Et al (2013 : 45) the value of the exchange rate (exchange rate) is also very influential on the increase in the number of islamic bank assets, so the effect on the ability of islamic banks in increasing profits, where if the exchange rate rose, then the bank will easily increase the amount of assets in significant amounts, where the amount of the asset increases derived from the fee from the foreign exchange, then it will make the islamic bank can collect the amount of assets maximum in order to increase the amount of income in order to improve the disbursement of capital to the various products of islamic banks.

A capital injection of foreign exchange gains this can be done to increase profits for the results, where profit for the results of this will impact on the increase in profit level for the results of savings products between islamic banks and their customers. On the contrary, if the value of the exchange rate weakened, then the bank will be difficult to increase the number of assets in significant amounts, where the amount of assets will tend to be decreased or a little increased, where islamic banks will not get the profit (fee) of the foreign exchange akbat from the exchange rate weakened. This means that islamic banks can not collect the amount of assets maximum in order to increase the amount of income in order to improve the disbursement of capital to the various products of islamic banks. Disbursement of capital from a foreign exchange loss this could not be done to increase profits for the results, where for this result will impact on the decrease in the profit level for the results of savings products between islamic banks and their customers.

According to Antonio (2012 : 33) level for the results of the savings that is owned by the islamic bank are in accordance with the wishes of the customer, i.e. has a profit sharing that can benefit the customer will be implemented if the inflation rate hits a low, as well as the value of the exchange rate tends to strengthen. If the level for the results can satisfy the customer, then the customer will tend to be loyal and want to continue to use the savings products of sharia banks. The situation is very influential on the increase in profit that will be obtained by the sharia bank in Indonesia, where the increase in profit level for the results between the bank and the customer will be the one a valuable contribution in increasing the profits of islamic banks, where the donation benefits will be able to enhance the amount of assets for the sustainability of the operations of the islamic bank itself.

In addition to the three factors above, external factors that affect the growth of islamic banking, namely the growth of PDB. The macroeconomic conditions will affect the company's operations in terms of policy-making relating to banking performance. Macroeconomic variables that can affect the company's financial performance, namely the level of gross domestic product is the value of the goods or services in a country produced by factors of production owned by residents of that state and a foreign country. PDB reflects the activities of residents in a country in producing certain goods in a certain period of time. Linkage of PDB to the world of banking is where the PDB is related to saving and investment. While one 
of the activities of the bank as an institution of mediation leading sector the financial is to collect funds from the public and channel it in the form of investment. The advantage of the investment that will be part of the assets of islamic banks. if PDB rises, then it will be followed by the increasing of people's incomes so that the ability to save money (saving) and use of financing products for both also increases. The increase in saving and an increase in a refund of credit from financing (NPL) will affect the assets of islamic banks (Sukirno, 2000).

Based on the information already described above, then the relationship between inflation, exchange rates (exchange rate), the rate for the results, the PDB and an increase in assets of islamic banks will be can be seen in Table 1.2 and the following.

Table 1.2: Data on Inflation, Exchange rates (exchange Rate), PDB, For the Results and the Amount of Assets of Islamic Banks in the Period from 2009 to 2019

\begin{tabular}{|l|l|l|l|c|c|}
\hline Year & $\begin{array}{l}\text { Inflation } \\
(\boldsymbol{\%})\end{array}$ & $\begin{array}{l}\text { Exchange Rate (Closing Rate Annual) } \\
(\mathbf{R p})\end{array}$ & $\begin{array}{l}\text { PDB } \\
(\boldsymbol{\%})\end{array}$ & $\begin{array}{l}\text { For The Results } \\
(\mathbf{R p})\end{array}$ & $\begin{array}{l}\text { Total Assets Of Islamic Banks } \\
(\mathbf{R p})\end{array}$ \\
\hline 2009 & 2,78 & 9.447 & 4,70 & 3.053 .645 .000 & 66.090 .000 .000 \\
\hline 2010 & 6,96 & 9.036 & 6,38 & 4.136 .712 .000 & 97.619 .000 .000 \\
\hline 2011 & 3,79 & 9.113 & 6,17 & 9.120 .920 .000 & 146.467 .000 .000 \\
\hline 2012 & 4,30 & 9.718 & 6,03 & 8.523 .827 .000 & 196.018 .000 .000 \\
\hline 2013 & 5,90 & 12.250 & 5,58 & 11.272 .229 .000 & 242.276 .000 .000 \\
\hline 2014 & 6,70 & 12.502 & 5,08 & 3.320 .471 .000 & 272.545 .000 .000 \\
\hline 2015 & 3,35 & 13.795 & 4,78 & 5.457 .850 .000 & 296.262 .000 .000 \\
\hline 2016 & 3,02 & 13.436 & 5,03 & 3.522 .260 .000 & 356.504 .000 .000 \\
\hline 2017 & 3,61 & 13.548 & 5,07 & 6.554 .031 .000 & 424.181 .000 .000 \\
\hline 2018 & 3,13 & 14.481 & 5,17 & 3.285 .100 .000 & 477.827 .000 .000 \\
\hline 2019 & 2,72 & 13.901 & 5,06 & 2.086 .800 .000 & 624.684 .000 .000 \\
\hline
\end{tabular}

Source :www.ojk.go.id and www.bps.go.id

Based on Table 1.2 above it can be concluded that there are fluctuations in inflation, exchange rate and the tendency of PDB is declining, where the fluctuations of inflation and the value of swapping as well as a decline in PDB that occurred make the a decline of income for the results of islamic bank in Indonesia, where the decline in income for these results does not make the assets of islamic banks decreases. This is because the principles always held by islamic banks, i.e. a system of principles for the results and not the principle adopted by the conventional banks, namely the system of capital tend to use a system of interest in each of its operational activities, where the system for the results this always gives the advantage to the customer in any conditions, although it was a little. This situation indicates that with increasing and declining inflation, it will be increasingly difficult for islamic banks to be able to consistently increase revenue for the results of savings products and an increase in a refund of the credit financing of the islamic bank, so that inflation and exchange rate affect each other against income for the results.
The increase in assets occurred in the period 2009-2019 Year could not help significantly in boosting the growth of capital to finance the profit for results from the products of islamic banks, because the assets acquired increased, but only a little bit of funds disbursed to increase profits for the product results in savings between the customer and the islamic bank, so that on the one hand the funds obtained can not increase profits for the results of the customer significantly, on the other hand the acquired funds or the profit earned can not boost an increase in profits for the bank's results significantly, where most of the increase in assets is made to cover the other operational, so that the benefits could not increase the bank's ability in helping to increase the participation of the bank in order to help the community in improving the purchasing power or consumption, so the role of the islamic banks is still not visible due to the ability of islamic banks is still not optimal in collecting funds community savings to enhance the ability of public consumption. 


\section{LITERATURE REVIEW Exchange Rate}

The exchange rate is a record (quotation) the market price of foreign currency (foreign currency) in the price of domestic currency (domestic currency) or reciprocal, i.e. the price of domestic currency in foreign currency (Darmawi, 2012: 35). In another case it is said that the value of the exchange rate present level of prices of exchange from one currency to other currencies, and are used in various transactions, among others, international trade transactions, financing transactions banking, as well as fund raising by banks in the form of savings or deposits with the use of foreign currency. (Huda, 2013: 47).

\section{For The Results}

For the results is the distribution of the results of operations that has been done by the parties who made the agreement, namely the customer and the party of islamic banks (Karim, 2010: 76). For the result is also a division on the results of operations that has been done by the parties who made the agreement, namely the customer and the islamic bank (Ismail, 2011 :96).

\section{Inflation}

Inflation is a symptom of the rise in the prices of goods that are common and continuous. Inflation is the increase in the prices of goods and services, which occurs because of the demand increase is large compared with the supply of goods in the market (Sukirno, 2016:15). In other words, too much money chasing down stuff that is too little (Rahardja and Manurung, 2010:16)

\section{Gross Domestic Product}

Gross Domestic product in the English Gross Domestic Product (GDP) is defined as the value of the goods and services that are produced within the country in a given year. PDB measures the value of goods and services produced in a region of the country (domestic) without distinguish the ownership/ citizenship in a given period. The national approach has a very vital role for a country. At the time the national income rises, it is assumed that the people materially improve its position or vice versa, of course, after divided by the number of population (Mankiw, 2012: 80).

\section{Assets}

Assets are all economic resources or assets owned by an entity that is expected to benefit business in the future (Antonio, 2012: 60). Meanwhile, according to SFAS No.16 Revised 2011 mentioned that the asset is all wealth owned by a person or company, both tangible and intangible valuable or worth the that will bring benefits for a person or company. The future economic benefits embodied in an asset is the potential of these assets to be contributed, directly or indirectly, of cash flows and cash equivalents to the company.

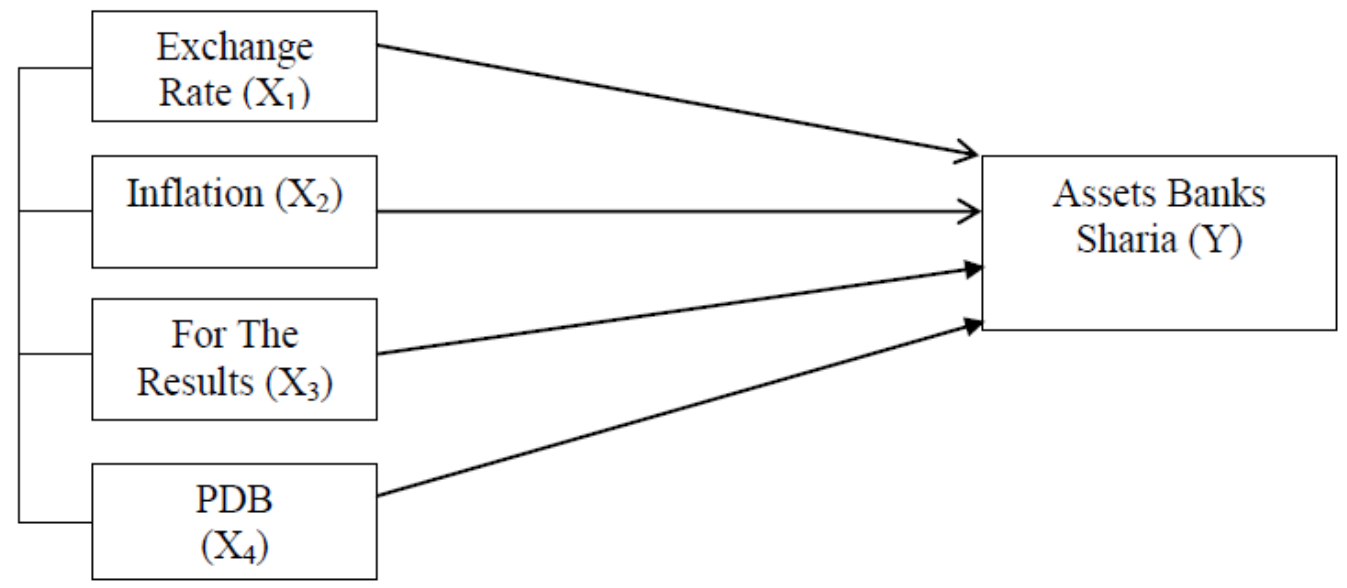

Figure 1. Conceptual Framework 


\section{Hypothesis}

Based on the background research and the relationship between variables, then the research hypothesis:

1. The Exchange rate has a positive effect on Islamic Banking Assets in Indonesia.

2. Inflation negatively affect the Assets of Sharia Banking in Indonesia.

3. For the Results of the positive effect on the Islamic Banking Assets in Indonesia.

4. PDB has a positive effect on Islamic Banking Assets in Indonesia.

5. The value of the Exchange rate, For the Results, Inflation, and PDB are simultaneously positive influence on the Islamic Banking Assets in Indonesia.

\section{MATERIAL AND METHODS}

The author will use the techniques of Regression analysis of Panel Data using data pooling cross section and time series, where the data is processed using Eviews 10 and can be used to see the relationship between the variables that become options to see if there was a variable-a variable that has a major role to affect inflation directly. While the writing technique of this research is using the technique of literature studies, which explore and analyze a variety of information related in the various books and library materials to the other, While the data is processed from data published by Bank Indonesia.

The population in this study is the quarterly financial report 10 commercial banks and sharia business units Year 20152019. Sampling in this study using purposive sampling technique. Purposive sampling is a method of determining in a sample with certain criteria, so that the number of samples in this study amounted to 200 observation data.

The type and Source of Data. Data is information that can give you an idea about a situation, the Data obtained need to be processed to be able to answer the problems formulated in the research, Based on how to obtain the data used in this research is secondary data, According to the classification of the collection of data is time series data monthly, the Data used in this research is quantitative data. This study uses secondary data with the data type of the series of time (time series), i.e. the monthly data of the year 2015 until 2019, the data used in this study are taken from the quarterly financial statements of 10 commercial banks in Indonesia. Inflation Data triwula nan years 2015-2019, as well as exchange rate data is quarterly year 20152019.

This study uses the technique of regression analysis of panel data, namely pooling cross section and time series. Cross section Data is observation data on some of the research subjects in one time, for example, in one year. While time series Data is observation data on the one subject of research is observed in one period of time.

\section{RESULTS AND DISCUSSION The Influence Of Exchange Rates On The Growth Of Assets Of Sharia Banks}

Exchange rate is a comparison of the exchange value of a Country's currency with the currency of a foreign Country or a comparison of exchange rates between countries. Based on the results of partial test (t-Test) in Table 4.11 it is known that the exchange rate has a positive effect but not significant on the variable development of assets of sharia banks in Indonesia in the period of years 2015-2019. This is evidenced by the results of the value $t$ calculate equal to 1.079975, while the probability value (F-statistics) of 0,2816 > 0,05 . where these results show the variable exchange rate has no significant effect on the development of assets of sharia banks in Indonesia.

Increase in the exchange rate of foreign currencies against sharia banks in Indonesia tend not to have an impact on the development of the assets of islamic banks, since market share of islamic banks are still a little bit in compare with conventional banks. There are only a few islamic banks have a stock of foreign exchange while the rest save currency in the form of rupiah so 
that the impact of the exchange rate changes do not particularly affect the assets of islamic banks.

Then also in the islamic banking system in Indonesia, not all Islamic Banks in Indonesia, including in Islamic Banks foreign Exchange. From a Total of 11 islamic Banks registered in Bank Indonesia, only 4 islamic banks that belong to the Islamic Banks or banks that do foreign exchange transactions, namely (Banks BNI Sharia, Banks Sharia Mandiri, Banks Muamalat and Bank BRI Sharia) the rest of the 7 other islamic banks not included in islamic banks foreign exchange or not do foreign exchange transactions. So on average if there is a change of the exchange rate then not too have an impact on the changes in asset of islamic banks.

The orientation of the products offered by islamic banks are still limited in domestic level, not to reach out widely in the international market because as we know the system of islamic banks, which adhere to the system of islamic law based on Qur'an and Hadith so it is less in the lyrics by other countries that the majority of nonmuslims.

The results of this research in accordance with research conducted by Melly (2009) that the value of the currency exchange rate does not significantly influence the profitability of islamic banks in Indonesia.

And also in accordance with the results of the study of Sekar Cahyani Arumdalu (2018), which states that the exchange rate has no significant effect on islamic banks in Indonesia. This is in accordance with research Ahmad Chumaidi, Tarmizi and Muslikhati (2017) with the title "the Influence of Fluctuations in the Exchange rate of the Rupiah Against the Ratio of Growth of Assets of Sharia Banking", where this research describes that there is a positive influence between the fluctuations of the exchange rate with the ratio of asset growth, where the presence of the strengthening and weakening of the exchange rate can affect the assets of the islamic banking, where the strengthening of the rupiah, it tends to increase the current assets of islamic banks, where the current assets is closely related to the decline of NPL (bad loans), where the decline in NPF is closely related with the improvement in the level of refund from the customers, so that islamic banks can increase the availability of funds for its operations, including increasing the profits and assets of the islamic bank itself.

\section{The Effect Of Inflation On The Growth Of Assets Of Sharia Banks}

Inflation is a rise in the price level in general and goods/ commodities and services during a certain period of time. Inflation can be considered as a monetary phenomenon because the decline in the unit value calculation monetary to a commodity.

Based on the results of testing it is known that Inflation has a positive effect but not significant on the variable of growth of assets of sharia banks in Indonesia in the period of years 2015-2019. This is evidenced by the results of the $t$-by 0.044550 , while the value of the probability is of $0.9645>0,05$, where these results show the variable of Inflation has no significant effect on the development of assets of sharia banks in Indonesia.

If the value of the inflation experienced an increase or decrease of it does not affect the performance and development of the bank's assets. That is because islamic banks have a durability which is strong against changes in the inflation rate compared to conventional banks. In doing financing (product/service) islamic banks use some sort of contract, good agreement with the pattern of the traveler, for the results, sell buy, or rent. The determination of The use of a variety of contract are adjusted with the needs of customers of borrowers, this is done one of them with the aim to minimize the occurrence of risk financing and also bad credit.

Then also basically high inflation reflects of the rise of goods-the goods that 
make the value of the circulation of money can be reduced due to the price increase. Such price increases can reduce the purchasing power of the community so that the community is reluctant to spend (consumption) and better save the money to the bank so that the funds saved in the bank to be increased.

On the theory of the Fisher effect says that when subjected to a rise in inflation by one percent then it will result in a rise in interest rates by one percent. Like the incident in mid-1997, many of the conventional can not rise due to the monetary crisis that occurred in Indonesia, precisely islamic banks still exist even still earn a profit. Conventional banks contracted the virus Negative Spread (losses due to interest rates on deposits higher than loan interest). While islamic banks still thrive without experiencing the negative spread. And since in the Islamic Economy it is not allowed to use a system of interest then in islamic banking will raise the Ratio For the Results that are used by islamic banks as a step to overcome so that customers do not turn to a conventional bank which offers high interest so that by raising the profit sharing ratio will make the customer will keep their funds in islamic banks.

The results of this study correspond with previous research conducted by Syahirul Alim (2014) which states that inflation partially has positive influence and not significant to Return On Assets of Islamic Banking. This is because the system of islamic banks that do not adhere to the system of interest like a conventional bank, so the money is managed not too experienced turmoil when experiencing inflation.

The results of this study are also in accordance with the research Andriani (2016) which states that inflation in parisa has a positive effect on islamic banking. This means that if inflation rises then the performance of the islamic banking is getting better. The purchasing power of people decreases the demand for financing is increasing, this makes the islamic banks free from idle money (money sleep).

\section{The Influence For The Results Of The Growth Of Assets Of Sharia Banks}

Sharia banking introducing a system in society with the term of Revenue Sharing, i.e. the system for results that are calculated from the total income of the management of the fund without deducting the cost of fund management. More details of Revenue sharing in the sense of banking is the calculation for the results based on the total of all income received before deducting the costs that have been incurred to obtain these revenues.

Based on the results of testing it is known that for the results positive and significant effect on the variable development of assets of sharia banks in Indonesia in the period of years 2015-2019. This is evidenced by the results of the value $t$ calculate equal to 5.921264 , while the probability value is $0,000<0,05$, where the results of this showed a variable for the result of significantly influence the variable development of the assets of islamic banks.

Mishkin (2008:128) explains in the Theory of Asset Demand (theory of asset demand) that the amount of demand and positively related to forecast returns relative to alternative assets. In short it can be concluded that the owners of the funds are interested to save your funds in the bank based on the interest rate or the rate for the promised results (Muhammad, 2005:264).

The customer in placing their funds in islamic banks is still influenced by the motive for profit (profit) so if the rate for the results of the bank (the ratio) the greater the greater the third party funds especially deposits that are stored in the bank and in the end will increase the asset bank of the sharia. In the theory of money supply, if the price rises then goods offered has increased and vice versa.

This is in accordance with previous research Nisa and Tati (2015) which states that the partial results for the positive and 
significant effect on islamic banks in Indonesia (At PT. Banks Sharia Mandiri).

The results of this study are also in accordance with the performed by Cleopatra (2008) showed that the percentage of profit sharing ratio has a positive effect on the growth of assets of sharia banks.

\section{The influence of PDB On the Growth of Assets of Sharia Banks}

Based on the results of testing it is known that PDB has positive and significant effect on the variable of growth of assets of sharia banks in Indonesia in the period of years 2015-2019. This is evidenced by the results of the $t$ value 5.685948, while the probability value (F-statistics) by 0,0000 0.05 indicates variable PDB variables significantly influence the development of the assets of islamic banks.

According to Huda, et al (2013 : 90) PDB (economic growth) influence the growth of islamic bank assets, where the event of increase in PDB or economic growth high, it will be able to improve the national economy, thereby affecting the increase in earnings of some companies, where one business that has increased profits significantly is islamic bank. if PDB rises, then islamic banks will experience an increase in hp, increase in PDB will increase the maximum profit for businesses, so employers will be able to pay the credit owed to the bank, whether it is business credit, and working capital loans. Ability to pay high credit by entrepreneurs impact to the decline in receivables non-performing loans (NPL), as a result of the decline in the NPL of islamic banks can collect funds for its operations, including to increase profits for the proceeds through the banking products, either through islamic savings and islamic finance, as a result influencing the growth of assets of islamic banks itself, where the asset growth will increase and the impact on the increase in operating capital in operating activities in the future.

According to Ismail (2011: 41) if PDB drops, then the economic situation to be down, so that impact to the decline in operating income, as a result of employers can't pay kresit already maturing due to a decline in revenue. This is an impact to the increase in NPL, as well as the inability of islamic banks in raising capital for its operations, such as increasing income to savings products and financing. As a result, the effect on the increase in current assets, so the growth of assets of islamic banks will tend to decrease.

This is according to research Noni Rozani (2017) with the title "Analysis of the Interdependence of Inflation, GDP, EXC, For the Results, and JUB To the Development of Sharia Banking Assets In Indonesia", where the results of this study stated that GDP affects significantly to the growth of assets, which at the time experienced an increase in GDP are able to improve the economy and repair business, where business operations will experience the maximum profit, thus affecting the occurrence of the increase in credit payments in accordance with the due date. This will affect the occurrence of NPLS. As a result, islamic banks can collect funds for its operations, including to increase profits for the proceeds through the banking products, either through islamic savings and islamic finance, as a result influencing the growth of assets of islamic banks itself, where assets of islamic banks will rise and could increase the capital for the operational activities in the future. On the contrary, when experiencing a decline in GDP can lower the economic condition and repair business, where business operations would suffer losses, so the effect against the occurrence of a decrease in credit payments in accordance with the due date. This will affect the occurrence of the increase in NPLS. As a result, islamic banks can not collect funds for its operational activities, including to increase profits for the proceeds through the banking products, either through islamic savings and islamic finance, as a result influencing the growth of assets of islamic banks itself, where assets of islamic banks will tend to fall and affect all activities of the islamic bank itself. 


\section{CONCLUSIONS AND \\ RECOMMENDATIONS CONCLUSIONS}

Based on the results of the research can be summed up as follows:

1. Based on the results of the data analysis it can be concluded that the partial indicates that the variable exchange rate has a positive effect but not significant on the variable of islamic bank assets in Indonesia with the results of the regression has the value $t$ calculate equal to 1.079975 and the probability of 0,2816 , i.e. $>0.05$ the.

2. Partial indicates that the variable of inflation has a positive effect but not significant on the variable of islamic bank assets in Indonesia with the results of the regression has the value $t$ calculate equal to 0.044550 and the probability is of 0.9645 i.e. $>0,05$.

3. Partial indicates that the variable for the results positive and significant effect on the variable of growth of assets of sharia banks in Indonesia with the results of the regression has the value $t$ calculate equal to 5.921264 and the probability of 0.000 which $<0,05$.

4. Partial indicates that the variable GDP has positive and significant effect on the variable of growth of assets of sharia banks in Indonesia with the results of the regression in PDB has the value $\mathrm{t}$ calculate equal to 5.685948 and probability of $0.0000<0,05$.

5. Simultaneously shows that the variables of exchange rate, inflation, the PDB has positive and significant effect on the variable of growth of assets of sharia banks in Indonesia with the results of the regression of the known values of $F$ count equal to 521.87 and the probability $\mathrm{F}$ of 0,0000 .

\section{RECOMMENDATIONS}

The advice of researchers from the research that has been done is as follows:

1. Should islamic banks should pay attention to the motion of inflation in each month. It is intended that islamic banks set up planning to increase assets. Islamic banks can offer islamic products new that can add to the value, where the new product is intended to increase the capital in order to cover this makes It easy for islamic banks to raise capital to finance the operational activities that can improve the growth of the asset the current high.

2. Should islamic banks should always apply the system for the results that are appropriate and beneficial for the customer. It aims to be able to attract customers as much as possible, and be able to increase the profit, where this profit can cover the NPF, and the bias used to finance its operations, so as to improve the growth of the asset the current high.

3. For researchers selanjtnya should be added to the variable ROA and ROE, where the addition of this variable can be useful for researchers selanjtnya to measure how big the influence of ROA and ROE when the occurrence of the fluctuations on the growth of assets of islamic banks itself.

\section{Acknowledgement: None}

\section{Conflict of Interest: None}

\section{Source of Funding: None}

\section{REFERENCES}

1. Affandi, Faisal, 2016, "Analisis Pengaruh Tingkat Inflasi, Nilai Tukar, BI Rate, dan Suku Bunga Bank Konvensional Terhadap Margin Bagi Hasil Deposito Mudharabah Perbankan Syariah Di Indonesia Periode 2010-2015", Jurnal Ekonomi At-Tawassuth, No. 1, Vol. I.

2. Amanah, Tuty, 2019, "Pengaruh Produk Domestik Bruto, Inflasi, BI Rate dan Nilai Tukar Terhadap Pembiayaan Bermasalah Dalam Perspektif Ekonomi Islam (Studi Pada BPRS di Indonesia Periode 20082018)", Skripsi Fakultas Ekonomi dan Bisnis Islam Universitas Islam Negeri Raden Intan Lampung. 
3. Asrina, Putri, 2015, “Analisis Pengaruh PDB, Nilai Tukar Rupiah, Non Performing Finance (Npf), Bopo Terhadap Profitabilitas (ROA) Perbankan Syariah Di Indonesia Periode 2008-2013", Jom FEKON,Vol. 2 No. 1. Februari 2015.

4. Aulia, Syifa, Suci, 2018, "Pengaruh Inflasi dan Nilai Tukar Terhadap Pendapatan Bagi Hasil Mudharabah Pada Bank Umum Syariah (Periode 2013-2017), Skripsi Fakultas Ekonomi dan Bisnis Universitas Islam Negeri Raden Intan Lampung.

5. Antonio, M. Syafi'i. 2012. Bank Syariah dari Teori Ke Praktek. Yogyakarta: Gema Insani.

6. Arifin, Zainul. 2016. "Dasar-dasar Manjemen Bank Syariah", Azkia Publisher, Tanggerang.

7. Basuki, Agus Tri dan Prawoto, Nano. 2016. Analisis Regresi Dalam Penelitian Ekonomi \& Bisnis : Dilengkapi Aplikasi SPSS \& EVIEWS. Depok : PT Raja grafindo Persada.

8. Darmawi, Herman, 2012, Manajemen Perbankan, Jakarta :Bumi Aksara.

9. Ekananda, Mahyus, 2015, "Analisis Data Time Series :Untuk Penelitian Ekonomi, Manajemen dan Akuntansi", Jakarta: Mitra Wacana Media.

10. Gujarati, N. Damodar, 2013, Dasar-Dasar Ekonometrika, Jakarta : Salemba Empat.

11. Huda, Dkk, 2013, Ekonomi Makro Islam :Pendekatan Teoritis, Jakarta : Prenamedia.

12. Ismail, 2011, Perbankan Syariah, Jakarta :Kencana Prenada Media Group

13. Karim, Adiwarman A. 2010. Ekonomi Makro Islam. Jakarta: Raja Grafindo Persada.

14. Mankiw, Gregory N. 2012. Principles of Economics Pengantar Ekonomi Makro. Edisi Asia. Alih Bahasa Chriswan Sungkono. Jakarta. Salemba Empat. 2006.

15. Frederic, Mishkin, Ekonomi Uang. Perbankan dan Pasar Keuangan, (Jakarta : Salemba Empat, 2008), hlmn 13.

16. Otoritas Jasa Keuangan (OJK). Desember 2016. Islamic Banking Statistic, Financial Services Authority, Republic of Indonesia, Bank Licensing and banking Information Department, Jakarta.

17. Otoritas Jasa Keuangan (OJK). Desember 2019. Islamic Banking Statistic, Financial Services Authority, Republic of Indonesia, Bank Licensing and banking Information Department, Jakarta.
18. Pratama, Rahardja dan Manurung, Mandala, 2010, Teori Ekonomi Makro, Jakarta : LPFEUI.

19. Putra, Erlangga, Dwiki, 2017, "FaktorFaktor Yang Mempengaruhi Tingkat Pertumbuhan Total Aset Perbankan Syariah Di Indonesia Periode 2011-2015”, Skripsi Fakultas Ekonomi dan Bisnis Universitas Islam Negeri Syarif Hidayatullah Prodi Perbankan Syariah.

20. Purba, Nova dan Darmawan, Ari, 2018, "Pengaruh Pertumbuhan Produk Domestik Bruto Dan Inflasi Terhadap Non Performing Finance Bank Syariah (Studi Pada Bank Umum Syariah Di Indonesia Periode 20142016)", Jurnal Administrasi Bisnis (JAB), Vol. 61 No.2, Agustus 2018.

21. Rohmana, Yana, 2013, Ekonometrika Teori dan Aplikasi Dengan Eviews, Bandung : Laboratorium Pendidikan Ekonomi dan Koperasi FPEB UI.

22. Rozaini, Noni, 2017, "Analisis Interdependensi Inflasi, GDP, EXC, Bagi Hasil, dan JUB Terhadap Perkembangan Aset Perbankan Syariah Di Indonesia", Disertasi Progra Pasca Sarjana Universitas Islam negeri Sumatera Utara Prodi Ekonomi Syariah.

23. Setiawan, Adi, 2009, Analisis Pengaruh Faktor Makro Ekonomi, Pangsa Pasar dan Karakteristik Bank Terhadap Profitabilitas Bank Syariah (Studi Pada Bank Syariah Periode 2005-2008), (Online). Jurnal Bisnis dan Manajemen 2 (3). (diakses 26 Oktober 2016).

24. Sugiyono, 2012, “ Metode Penelitian Bisnis", Cetakan ke 12, Bandung : Alfabeta.

25. Sukirno, Sadono. 2016.”Pengantar Teori Makro ekonomi".Edisi Ketiga, Jakarta: Rajawali Press.

26. Supriyanto, Bagus dan Sari, Permata, Sinta, 2019, "Faktor-Faktor Internal Yang Mempengaruhi Pertumbuhan Aset Bank Umum Syariah Selama Satu Dekade (20092018)", Seminar Nasional Call Paper, Seminar Bisnis Manajemen (SAMBIS2019), ISSN, h. 1474-2685.

27. Tanjung, Hendri dan Abrista Devi. 2013. "Metode Penelitian Ekonomi Islam", Jakarta: Gramata Publishing.

28. Tarmizi, Churnaidi, Achmad dan Muslikhati, 2017, "Pengaruh Fluktuasi Nilai Tukar Rupiah Terhadap Rasio Pertumbuhan Aset Perbankan Syariah", Jurnal Ekonomi 
Muhammad Arif et.al. Analysis of the effect of exchange value, inflation, product sharing and gross domestic products on development Sharia banking assets in Indonesia.

Universitas Muhammadiyah Malang, No. 2, Vol II.

29. Undang-Undang Republik Indonesia Nomor 3 Tahun 2004 tentang Perubahan Atas Undang-Undang Republik Indonesia Nomor 23 Tahun 1999 tentang Bank Indonesia.

30. Undang-Undang No. 7 Tahun 1992 Tentang Perbankan.

31. Undang-Undang No. 10 Tahun 1998 Tentang Perbankan

32. Undang-undang Republik Indonesia Nomor 21 Tahun 2008 Tentang Perbankan Syariah.

33. Wijayanti, Yati dan Sudarmini, 2016, "Pengaruh Inflasi terhadap Nilai Tukar Rupiah (Studi Pada Bank Indonesia Pada Periode 2011-2015)", Jurnal pendidikan ekonomi FPIPS IKIP PGRI Madiun.
34. Widarjono, Agus, 2009, "Ekonometrika Pengantar dan Aplikasinya", Yogyakarta :Ekonisia.

35. Fatma, Laila. 2019. "Pengaruh Infasi dan Nilai Tukar Mata Uang Asing Terhadap Profitabilitas Perbankan Syariah di Indonesia. Skripsi. FEBI UINSU. Di akses 18 Januari 2021.

How to cite this article: Arif M, HB. Tarmizi SU, M. Syafi'i. Analysis of the effect of exchange value, inflation, product sharing and gross domestic products on development Sharia banking assets in Indonesia. International Journal of Research and Review. 2021; 8(6): 180-192. DOI: https:// doi.org/10.52403/ijrr.20210622 